\title{
METASOMATISM AND THE GENESIS OF KIMBERLITES AND ALKALI BASALTS
}

A.L.BOETTCHER (Department of Earth and Space Sciences and Institute of Geophysics and Planetary Physics, University of California, Los Angeles, Los Ange1es, California 90024)

J.R.O'NEIL (U.S. Geological Survey, Menlo Park, California 94025)

K.E.WINDOM (IGPP, University of California,Los Angeles, Los Angeles, California)

D.C.STEWART (Pennsylvania State University, University Park, Pennsylvania 16802) H.G.WILSHIRE (U.S Geological Survey, Menlo Park, California 94025)

Various lines of petrochemical evidence disclose that pervasive metasomatism of mantle lherzolite is precursory to or concomitant with anatexis in the production of many deep-seated alkaline basaltic magmas and kimberlites. For example, ultramafic mantle xenoliths in kimberlites and in alkali basalts, basanites and kindred rocks commonly exhibit evidence of metasomatic enrichment in $\mathrm{TiO}_{2}, \mathrm{~K}_{2} \mathrm{O}$, total $\mathrm{Fe}, \mathrm{H}_{2} \mathrm{O}$, etc. Evidence for this in many kimberlite xenoliths is abundantly manifest in the development of "secondary" phlogopite, i.e. phlogopite formed in the mantle, but subsequent to the crystallization of the primary mantle lherzolite. This process commonly converts the lherzolite to assemblages rich in clinopyroxene, amphibole, and other minerals in addition to the phlogopite (e.g. Lloyd and Bailey, 1975), which are abundant in kimberlites from many areas of the world (see Dawson and Smith, 1973).

We have selected for chemical and isotopic analysis a number of phlogopites that appear on the basis of textural evidence to be secondary, for conparison with those that have been classified by others as primary. The former occur as veins and overgrowths; the latter as discrete grains, such as the "primary" mica pictured by Dawson et al. (1970, plate 3) and Carswe11 (1975, Fig. 1-A). A facile examination of Table I discloses that the obviously secondary phlogopites are enriched in $\mathrm{TiO}_{2} \cdot$ Carswell previously pointed out that micas with high $\mathrm{TiO}_{2}$ contents have textural relationships suggestive of being secondary, which is in chorus with our findings. Titaniferous phlogopites postulated as primary, such as in the garnet lherzolite xenolith (BD 738) from Lashaine Volcano (Dawson et al., 1970) or the alkalic rocks from Jan Mayen (Flower, 1969) and West Kimberly (Prider, 1939), may be secondary.

The low-TiO ${ }_{2}$, high-Fe phlogopites in Table I, some of which are the cores for the high-TiO ${ }_{2}$ phlogopite rims, themselves commonly appear to be secondary (e.g. Kb-9-5 and $\mathrm{B}-131$ ). They exhibit reverse pleochroic schemes, previously reported in micas from kimberlites and alkalic ultramafic rocks (e.g. Wagner, 1914; Watson, 1955; Hogarth, 1964; Boettcher, 1967; Suwa and Aoki, 1975).

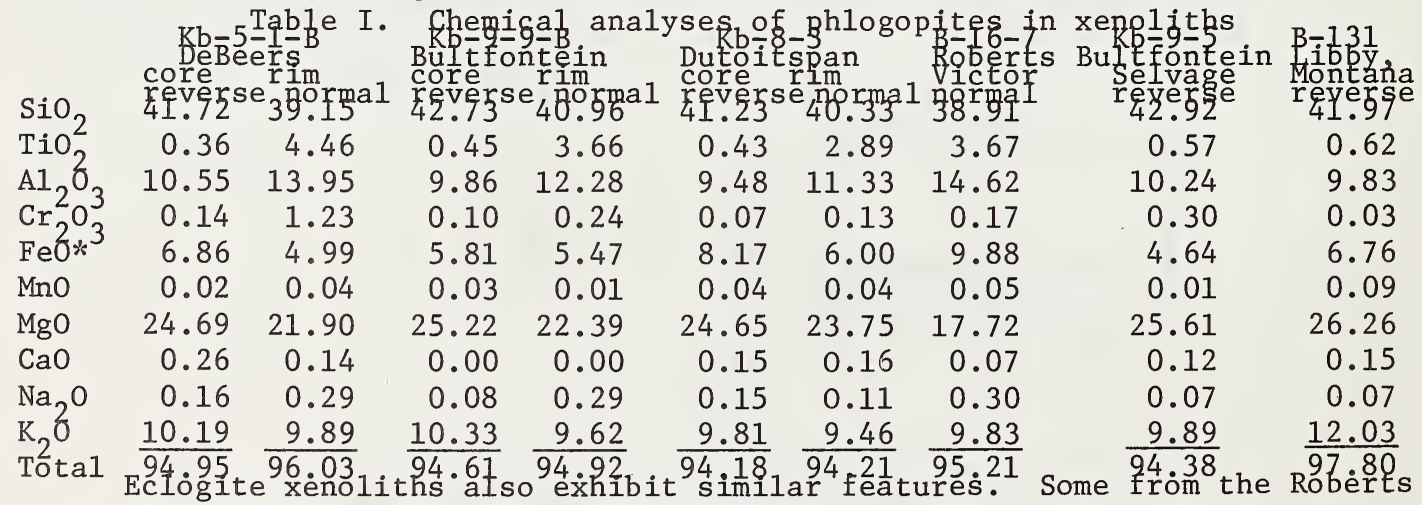

Victor Mine contain intergranular $\mathrm{TiO}_{2}$-rich phlogopite (Table I), potassic pargasite, analcime, augite, spinel, and plagioclase in an alkali-rich $\left(\mathrm{K}_{2} \mathrm{O}^{+}\right.$ 
$\mathrm{Na}, 0>12 \%$ ), carbonate-bearing groundmass (Windom and Boettcher, 1977; Switzer and Melson, 1969). Again, fluids similar to those discussed above and not contamination by the kimberlite per se are responsible for the metasomatism.

Xenoliths of spinel lherzolite in alkali basalts and basanites also exhibit evidence of such metasomatic alteration. As much as $50 \%$ of these xenoliths from many areas in North America and elsewhere contain pargasitic or kaersutitic amphiboles that crystallized after the primary therzolite assemblage but prior to incorporation of the xenoliths into the host magmas (e.g. Wilshire and Trask, 1971; Best, 1974; Francis, 1976; Stewart and Boettcher, 1977). The formation of this amphibole, commonly together with accompanying phlogopite, apatite, magnetite and other minor phases, is unrelated to contamination by the magma, and chemical and textural zonations of these and the primary lherzolite minerals are related to the emplacement of amphibolitic and pyroxenitic veins that pre-date incorporation of the lherzolite into the host magma. Chemical evidence reveals that pargasites in the spinel therzolite have been metasomatized to kaersutitic amphiboles during emplacement of these veins, and the kaersutite and clinopyroxene (rarely orthopyroxene and spinel) megacrysts in the lavas are disaggregated remnants of the veins, as previously proposed by Wilshire and Trask (1971). For example, minerals in spinel therzolite from Dish Hill, California show variations in the major elements as gradients strongly developed perpendicular to xenolith surfaces covered with rinds of amphibole (the rinds are remnants of veins); no gradients occur parallel to these surfaces. In traverses toward the rind from within the 1herzolite, amphiboles exhibit a relative increase in $\mathrm{TiO}_{2}(>250 \%)$, total $\mathrm{Fe}(>75 \%)$, and $\mathrm{K}_{2} \mathrm{O}(>50 \%)$ and a decrease in $\mathrm{Cr}_{2} \mathrm{O}_{3}(>80 \%)$. Megacrysts of kaersutite in the host basanite have compositions equivalent to those of the rind extrapolated to a distance of $>10 \mathrm{~mm}$ begyond the inner border of the rind.

$\delta^{18}, \delta \mathrm{D}$, and $\mathrm{H}_{2} \mathrm{O}^{+}$of the amphiboles and phlogopites in the xenoliths and megacrysts were determined for kimberlites, alkali basalts, and basanites. The range of values of $\delta D$ (relative to SMOW) for the micas is -60 to $-73^{\circ} / \%$, which is consonant with the values of "primordial" $\mathrm{H}_{2} \mathrm{O}$ obtained by Craig and Lupton (1976), Kuroda et al. (1977), and O'Neil (unpublished data). The narrowness of this range suggests that all $\mathrm{H}_{2} \mathrm{O}$ is fractionated into the hydrous minerals with no vapor present. Values of $\delta D$ for some amphiboles are lighter, ranging to $-111^{\circ}$ oo. $\delta^{18} 0$ for the micas and amphiboles ranges from 4.26 to 5.92 , typical of deep-seated materials. The micas, and especially the amphiboles, are poor in $\mathrm{OH}$ and rich in $\mathrm{F}$ and $\mathrm{Cl}$. For example, a Dish Hill kaersutite megacryst DHIA contains $0.40 \%$ (wt) $\mathrm{H}_{2} \mathrm{O}, 0.13 \% \mathrm{~F}, 0.1 \% \mathrm{Cl}$, and a large "oxyamphibole" component $\left(\mathrm{Fe}_{2} \mathrm{O}_{3}=13.76 \% ; \mathrm{FeO}=0.29 \%\right)$. These data suggest that the $\mathrm{a}_{\mathrm{H}_{2} \mathrm{O}}$ is consider-
ably less than unity, although a discrete vapor may have with the hydrous minerals.

We interpret the above data as evidence that anatexis or mobilization of mantle 1herzolite during the genesis of alkali basalts and kimberlites is subsequent to or concomitant with metasomatism by aqueous fluids rich in $\mathrm{Ti}$, Fe, $\mathrm{K}$, and other ions. Additional supportive evidence can be found in papers by Basu and Murthy (1977), Best (1975), Erlank (1976), Francis (1976), Frey and Green (1974), Lloyd and Bailey (1975), and Varne and Graham (1971). Primary alkali basalt and basanitic magmas unmodified by fractionation, such as those described from Australia (Kesson, 1973), Colorado Plateau (Best and Brimhall, 1974), Mauritius (Indian Ocean) (Baxter, 1976), and the Easter volcanic chain (Pacific Ocean) (Bonatti et al., 1977), are enriched in elements including $\mathrm{K}$, $\mathrm{Ti}$, etc., as well as $\mathrm{H}_{2} \mathrm{O}$. Different degrees of partial melting of the mantle could account for the differences between some enriched primary magmas and others (Baxter, 1976), but marked heterogeneity of the source regions is sup- 
ported by a plethora of geochemical data (Cox et al., 1976; Kesson, 1973; Sun and Hanson, 1975). The indifferences of the chemistry of alkali basalts to their environment of eruption, be it continental, oceanic, or island-arc, argues against crustal contamination as a viable explanation (see Schwarzer and Rogers, 1974). Migrating fluids associated with, say, mantle diaperism (Wilshire and Pike, 1975) or plumes (Bonatti et al., 1977) appear to have operated throughout much of the history of the mantle. Consequently, the chemistry of mantle samples has been altered by the very processes that have resulted in bringing them to the surface--Irving's (1976) Heisenberg uncertainty. The search for pristine mantle continues.

\section{REFERENCES}

Baxter, A. N. (1976) Geol. Soc. Am. Bu11. 87, 1028-34.

Basu, A. R., and Murthy, V. M. (1977) Geology, 5, 365-8.

Best, M. G. (1974) J. Geophys. Res. 79, 2107-13.

Best, M. G., and Brimhal1, W. H. (1974) Geol. Soc. Am. Bull. 85, 1677-90. Boettcher, A. L. (1967) J. Geol. 75, 526-53.

Bonatti, E., Harrison, C. G. A., Fisher, D. E., Honnorez, J., Schilling, J. -G., Stipp, J. J., and Zentilli, M. (1977) J. Geophys. Res. 82, 2457-78. Carswe11, D. A. (1975) Phys. Chem. Earth 9, 41 $\overline{7}-2 \overline{9}$.

Cox, K. G., Hawkesworth, C. J., and O'Nions, R. K. (1976) Contrib. Mineral. Petrol. 56, 173-180.

Craig, H., and Lupton, J. E. (1976) Earth Planet. Sci. Lett. 31, 369-85.

Dawson, J. B., Powel1, D. G., and Reid, A. M. (1970) J. Petrol. 11, 519-48. Dawson, J. B., and Smith, J. V. (1973) J. Petrol. 14, 113-31.

Erlank, A. J. (1976) EOS, 57, 597.

Flower, M. F. J. (1969) Earth Planet. Sci. Lett. 6, 461-6.

Francis, D. M. (1976) Contrib. Mineral. Petrol. 58, 51-61.

Frey, F. A., and Green, D. H. (1974) Geochim. Cosmochim. Acta 38, 1023-59.

Hogarth, D. (1964) Canadian Mineral. 8 , 136.

Irving, A. J. (1976) Amer. Mineral. 61, 638-42.

Kesson, S. E. (1973) Contrib. Mineral. Petrol. 42, 93-108.

Kuroda, Y., Suzuoki, T., and Matsuo, S. (1977) Contrib. Mineral. Petrol. 60, 311-15.

Lloyd, F. E., and Bailey, D. K. (1975) Phys. Chem. Earth 9, 389-416.

Prider, R. T. (1939) Mineralog. Mag. 25, 373- $\overline{87}$.

Schwarzer, R. R., and Rogers, J. J. W. (1974) Earth Planet. Sci. Lett. 23, 286-96.

Stewart, D. C., and Boettcher, A. L. (1977) Submitted to Geol. Soc. Amer.

Sun, S. S., and Hanson, G. N. (1975) Geology 3 , 297-302.

Suwa, K., and Aoki, K, (1975) 1st Prelim. Rept. Afr. Studies, Nagoya Univ., 60-64. Switzer, G., and Melson, W. G. (1969) Contr. Earth Sci., no. 1, 1-9.

Varne, R., and Graham, A. L. (1971) Earth Planet. Sci. Lett. 13, 11-18.

Wagner, P. (1914) The Diamond Fields of Southern Africa. Transval1 Leader.

Watson, K. D. (1955) Amer. Mineral. 40, 565-79.

Wilshire, H. G., Calk, L. C., and Schwarzman, E. C. (1971) Earth Planet. Sci.

Lett. 10, 281-84.

Wilshire, H. G., and Pike, J. E. N. (1975) Geology 3, 467-70.

Wilshire, H. G., and Trask, N. J. (1971) Amer. Mineral. 56, 240-55.

Windom, K. E., and Boettcher, A. L. (1977) Submitted to Geol. Soc. Amer. 